\title{
Hypochlorous acid selectively promotes toxicity and the expression of danger signals in human abdominal cancer cells
}

\author{
ERIC FREUND ${ }^{1,2}$, LEA MIEBACH ${ }^{1,2}$, MATTHIAS B. STOPE $^{3}$ and SANDER BEKESCHUS $^{1}$ \\ ${ }^{1}$ Centre for Innovation Competence (ZIK) Plasmatis, Leibniz Institute for Plasma Science and \\ Technology (INP Greifswald), D-17489 Greifswald; ${ }^{2}$ Department of General, Visceral, Thoracic, and \\ Vascular Surgery, Greifswald University Medical Center, D-17475 Greifswald; ${ }^{3}$ Department of Gynecology and \\ Gynecological Oncology, Bonn University Medical Center, D-53217 Bonn, Germany
}

Received June 16, 2020; Accepted January 18, 2021

DOI: $10.3892 / o r .2021 .8022$

\begin{abstract}
Tumors of the abdominal cavity, such as colorectal, pancreatic and ovarian cancer, frequently metastasize into the peritoneum. Large numbers of metastatic nodules hinder curative surgical resection, necessitating lavage with hyperthermic intraperitoneal chemotherapy (HIPEC). However, HIPEC not only causes severe side effects but also has limited therapeutic efficacy in various instances. At the same time, the age of immunotherapies such as biological agents, checkpoint- inhibitors or immune-cell therapies, increasingly emphasizes the critical role of anticancer immunity in targeting malignancies. The present study investigated the ability of three types of long-lived reactive species (oxidants) to inactivate cancer cells and potentially complement current HIPEC regimens, as well as to increase tumor cell expression of danger signals that stimulate innate immunity. The human abdominal cancer cell lines HT-29, Panc-01 and SK-OV-3 were exposed to different concentrations of hydrogen peroxide $\left(\mathrm{H}_{2} \mathrm{O}_{2}\right)$, hypochlorous acid $(\mathrm{HOCl})$ and peroxynitrite $\left(\mathrm{ONOO}^{-}\right)$. Metabolic activity was measured, as well as determination of cell death and danger signal expression levels via flow cytometry and detection of intracellular oxidation via high-content microscopy. Oxidation of tumor decreased intracellular levels of the antioxidant glutathione and induced oxidation in mitochondria, accompanied by a decrease in metabolic activity and an increase in regulated cell death. At similar concentrations, $\mathrm{HOCl}$ showed the most potent effects. Non-malignant HaCaT keratinocytes were less affected, suggesting the approach to be selective to some extent. Pro-immunogenic danger molecules were investigated by assessing the expression levels of calreticulin (CRT),
\end{abstract}

Correspondence to: Dr Sander Bekeschus, Centre for Innovation Competence (ZIK) Plasmatis, Leibniz Institute for Plasma Science and Technology (INP Greifswald), 2 Felix Hausdorff Street, D-17489 Greifswald, Germany

E-mail: sander.bekeschus@inp-greifswald.de

Key words: calreticulin, heat-shock protein, peritoneal carcinomatosis, reactive oxygen species and heat-shock protein (HSP)70 and HSP90. CRT expression was greatest following $\mathrm{HOCl}$ and $\mathrm{ONOO}^{-}$treatment, whereas $\mathrm{HOCl}$ and $\mathrm{H}_{2} \mathrm{O}_{2}$ resulted in the greatest increase in HSP70 and HSP90 expression levels. These results suggested that $\mathrm{HOCl}$ may be a promising agent to complement current HIPEC regimens targeting peritoneal carcinomatosis.

\section{Introduction}

Several types of tumor can metastasize on or into the peritoneum (1). Rates of $<30 \%$ have been reported (2), making peritoneal carcinomatosis (PC) a burden for patients and healthcare systems alike. Pancreatic carcinoma often is diagnosed late and shows aggressive growth and metastasization in the peritoneum, limiting effective therapies $(3,4)$. Similarly, colorectal and ovarian carcinoma display widespread localization in the abdominal cavity, which allows open field metastasization and generation of PC before diagnosis (5-7). Curative treatment is rarely achievable. For palliation, systemic chemotherapy is of low efficacy and causes strong side effects (8). The combination of cytoreductive surgery with hyperthermic intraperitoneal chemotherapy (HIPEC; peritoneal lavage with heated liquids containing chemotherapeutic agents) has similar limitations (9). For HIPEC, life expectancy and quality of life in patients with PC are low (10). Alternative treatments, such as laser-induced oxidation of peritoneal cancer, may prolong survival but have been shown to be impractical and cause severe side effects (11).

Reactive oxygen species (ROS) are increasingly recognized as critical agents in anticancer therapy (12-15). For instance, certain types of nanoparticle (such as metal oxides, carbon nanotubes and silver nanoparticles) promote stress of the endoplasmic reticulum and mitochondria via ROS (16-18). Certain chemotherapeutic agents, such as 5-fluorouracil, can lead to generation of intracellular oxidants, such as peroxynitrite $\left(\mathrm{ONOO}^{-}\right)$, in tumor cells (19). Anthracyclines also generate intracellular ROS (20). Some treatment strategies aim to directly generate ROS. These include photodynamic therapy (PDT), which locally generates singlet $\Delta$ oxygen via a photosensitizer (21). PDT also promotes pro-immunogenic properties in tumor cells (22). Similarly, gas plasma treatment generates a multiple types of reactive oxygen and nitrogen 
species (ROS/RNS) simultaneously (23-25). This is not only toxic to tumor cells but also promotes their immunogenicity via an increase in danger signals (26-28). Specific pattern recognition receptors (PRR) are sensed by evolutionary preserved structures, such as pathogen- and damage-associated molecular patterns [including ATP, heat-shock proteins, endoplasmic reticulum chaperon calreticulin (CRT)]. Innate immune cells are thus able to initiate quick and early responses against infection or extensive cell death in tissue. These mechanisms emphasize the important role of immunogenic cell death (ICD) in initiating an anti-tumor immune response (29-31).

Since the award of the Nobel Prize for Physiology or Medicine in 2018 for immune-checkpoint therapies, there has been an increasing awareness of combination of conventional treatment modalities with immunotherapy (32). For PC treatment, standard therapy includes the intraperitoneal administration of chemotherapeutics that directly reach tumor lesions but cannot stimulate immunity via danger signals derived from targeted cancer cells $(33,34)$. This limitation may be overcome by using liquids supplemented with ROS to not only generate cytotoxic responses in tumor cells but also render them more immunogenic by promoting the expression of danger signals (35). To this end, the present study compared three types of ROS, hydrogen peroxide $\left(\mathrm{H}_{2} \mathrm{O}_{2}\right)$, hypochlorous acid $(\mathrm{HOCl})$ and $\mathrm{ONOO}^{-}$, to investigate their ability to inactivate cancer cells and promote expression of markers associated with ICD (31).

\section{Materials and methods}

Cell culture. A total of three human abdominal cancer cell lines (HT-29 colorectal, Panc-01 pancreatic and SK-OV-3 ovarian cancer cells), as well as non-malignant HaCaT keratinocytes, were used. The HT-29 and Panc-01 cells were cultured in DMEM (Gibco; Thermo Fisher Scientific, Inc.), while SK-OV-3 and HaCaT cells were cultured in RPMI-1640 medium (PAN Biotech $\mathrm{GmbH}$ ). Both media were supplemented with $10 \%$ fetal bovine serum, $2 \%$ penicillin-streptomycin and $1 \%$ glutamine (all Sigma-Aldrich; Merck KGaA). Cells were cultured at $37^{\circ} \mathrm{C}, 5 \% \mathrm{CO}_{2}$ and $95 \%$ humidity in a cell culture incubator (Binder $\mathrm{GmbH}$ ). Subculturing was performed 2-3 times/week. In order to determine the cell count for downstream experiments at high precision, cells were stained with PI (Sigma-Aldrich; Merck KGaA) for $5 \mathrm{~min}$ at room temperature, and absolute counts were obtained using acoustic focusing flow cytometry (Attune Nxt; Thermo Fisher Scientific, Inc.) and Attune Nxt Software v. 2.7.0 (Thermo Fisher Scientific, Inc.). Cells were seeded at $1 \times 10^{5}$ cells in flat-bottom 24-well plates for flow cytometry or $1 \times 10^{4}$ cells in 96 -well plates (both Eppendorf) for imaging experiments. The outer rim of each plate was filled with double-distilled water to prevent surplus evaporation in the edge wells.

Oxidant treatment. $\mathrm{H}_{2} \mathrm{O}_{2}$ (Alfa Aesar; Thermo Fisher Scientific, Inc.), $\mathrm{HOCl}$ and $\mathrm{ONOO}^{-}$(both Carl Roth $\mathrm{GmbH} \& \mathrm{Co}$.) were diluted in PBS to obtain concentrations between $10 \mathrm{mM}$ and $0.1 \mu \mathrm{M}$. Cell culture medium was removed and $250 \mu \mathrm{l}$ (per $1 \times 10^{5}$ cells in 24 -well plates) or $25 \mu 1$ (per $1 \times 10^{4}$ cells in 96-well plates) individual oxidant-containing liquid was added to cells After $2 \mathrm{~h}$ of incubation at $37^{\circ} \mathrm{C}, 1,750$ (for 24-well plates) or $175 \mu \mathrm{l}$ culture medium (for 96-well plates) was added to the cells to restore preferred culture conditions with fully supplied nutrients. The cells were allowed to culture for $22 \mathrm{~h}$ prior to further downstream processing.

Metabolic activity. The total metabolic activity per well was analyzed based on cell capability to metabolize 7-hydroxy-3 H-phenoxazin-3-on-10-oxid (resazurin; Alfa Aesar; Thermo Fisher Scientific, Inc.) to fluorescent resorufin. Resazurin was added to wells at a final concentration of $100 \mu \mathrm{M}$ and incubated for $2 \mathrm{~h}$ at $37^{\circ} \mathrm{C}$ before fluorescence was quantified using a multimode plate reader (F200; Tecan Group Ltd.). The measurement was taken at $\lambda_{\mathrm{ex}} 535$ and $\lambda_{\mathrm{em}} 590 \mathrm{~nm}$.

Flow cytometry. Flow cytometry was performed to investigate cell death and analyze surface marker expression levels. For the collection of cells, cell culture supernatant and detached cells (obtained using accutase; BioLegend, Inc.) were transferred to v-bottom 96-well plates (Eppendorf) after centrifugation at $500 \mathrm{x}$ g for $5 \mathrm{~min}$ at room temperature. The plate was washed with PBS (PAN Biotech $\mathrm{GmbH}$ ) before one of the following mixes was added to the wells: i) DAPI (BioLegend, Inc.) and active caspase-3/7 detection reagent (Thermo Fisher Scientific, Inc.); or ii) DAPI, anti-CRT monoclonal antibodies conjugated with phycoerythrin (Enzo Life Sciences, Inc.; cat. no. ADI-SPA-601PE-F), anti-heat-shock protein (HSP)70 monoclonal antibodies conjugated with Alexa Fluor ${ }^{\circledR}$ (AF) 594 and anti-HSP90 monoclonal antibodies conjugated with AF 700 (both Novus Biologicals LLC; cat. nos. NBP1-77456AF594 and NB100-1972AF700, respectively). The staining was performed for $30 \mathrm{~min}$ at $37^{\circ} \mathrm{C}$ using $20 \mathrm{ng}$ antibodies per test and DAPI and caspase- $3 / 7$ reagent at a final concentration of $1 \mu \mathrm{M}$. Subsequently, the cells were washed twice and analyzed using a CytoFLEX S (Beckman Coulter, Inc.) four-laser flow cytometer. The excitation wavelength and bandpass filters for collecting fluorescence emission were $\lambda$ ex $405 \mathrm{~nm} / \lambda_{\mathrm{em}} 450-45 \mathrm{~nm}$ and $\lambda_{\mathrm{ex}} 488 \mathrm{~nm} / \lambda_{\mathrm{em}} 520-40 \mathrm{~nm}$, respectively, for master mix i); and $\lambda_{\mathrm{ex}} 405 \mathrm{~nm} / \lambda_{\mathrm{em}} 450-45 \mathrm{~nm}$, $\lambda_{\text {ex }} 561 \mathrm{~nm} / \lambda_{\text {em }} 585-42 \mathrm{~nm}, \lambda_{\text {ex }} 561 \mathrm{~nm} / \lambda_{\text {em }} 610-20 \mathrm{~nm}$ and $\lambda_{\text {ex }} 638 \mathrm{~nm} / \lambda_{\text {em }} 712-25 \mathrm{~nm}$ for master mix ii). Forward and side-scatter were also analyzed. Gating and quantification of cell numbers and fluorescence intensities was performed using Kaluza 2.1.1 analysis software (Beckman Coulter, Inc.).

Quantitative high-content imaging. In order to determine cytosolic glutathione (GSH) levels and mitochondrial redox status, cells were stained with $2 \mu \mathrm{M}$ GSH detection probe (Kerafast, Inc.) or $1 \mu \mathrm{M}$ mitotracker orange (MTO; Thermo Fisher Scientific, Inc.) for $90 \mathrm{~min}$ at $37^{\circ} \mathrm{C}$. Following exposure to oxidants, as aforementioned, cells were imaged using a high content imaging device (Operetta CLS; PerkinElmer, Inc.). The digital phase contrast (DPC) channel (pseudo-cytosolic signal), as well as the fluorescence channels for bound $\left(\lambda_{\mathrm{ex}} 390-420 / \lambda_{\mathrm{em}} 500-550 \mathrm{~nm}\right)$ or unbound GSH tracer or MTO $\left(\lambda_{\mathrm{ex}} 460-790 / \lambda_{\mathrm{em}} 570-650 \mathrm{~nm}\right)$, were imaged. The experimental setup, as well as the software-based quantification algorithms, were generated using Harmony high-content imaging and analysis software 4.9 (PerkinElmer, Inc.). For segmentation, cells were detected via DPC signal and the fluorescence of both GSH tracer or MTO channels was quantified. For algorithm-driven quantification, $\geq 1 \times 10^{4}$ individual cells in 
A

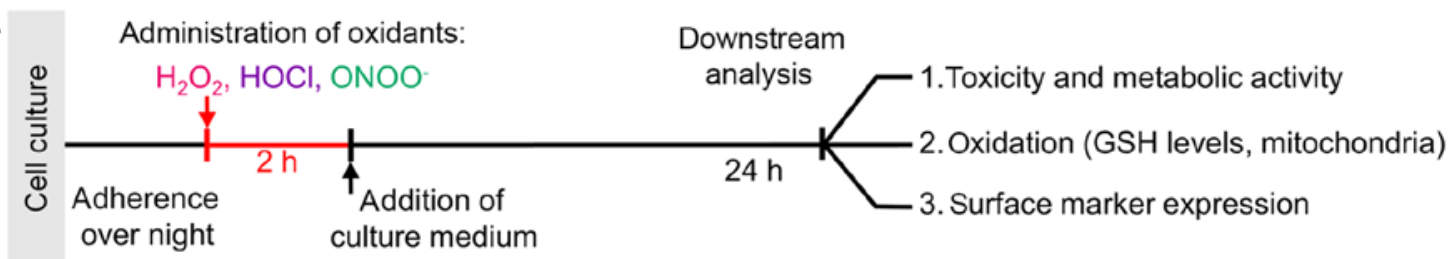

B

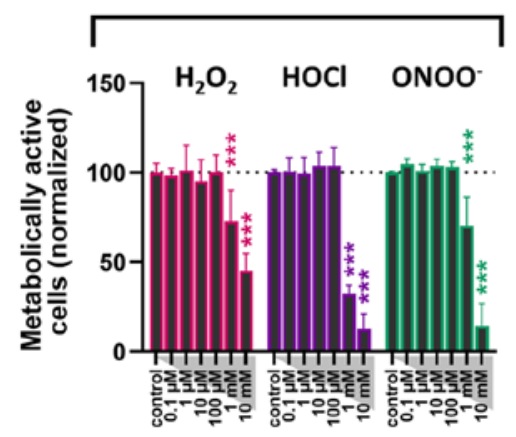

C

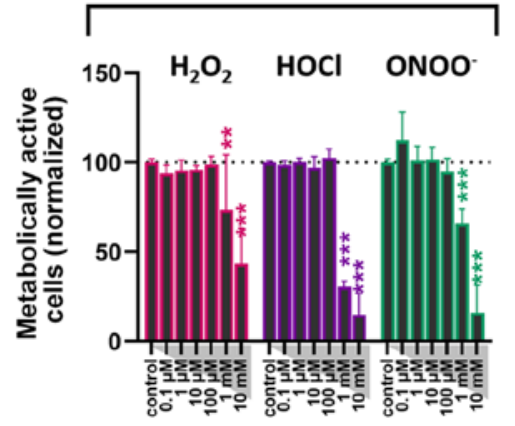

D

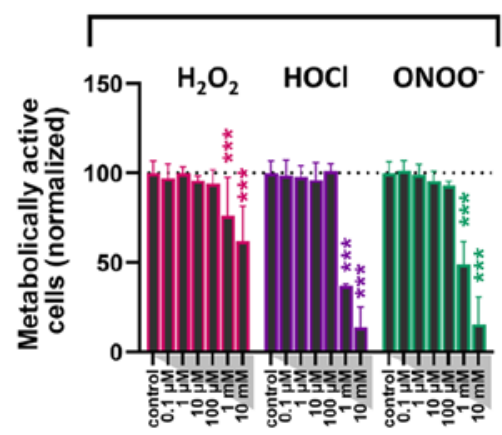

Figure 1. Experimental design and metabolic activity of tumor cells following exposure to oxidants in vitro. (A) Experimental design showing the administration of $\mathrm{H}_{2} \mathrm{O}_{2}, \mathrm{HOCl}$ or ONOO- to cancer cells. Percentage of metabolically active (B) HT-29, (C) Panc-01 and (D) SK-OV-3 tumor cells normalized to untreated controls at $24 \mathrm{~h}$ post-administration of oxidants. Data are from two to three independent experiments with several replicates each and are presented as the mean \pm SD. ${ }^{* *} \mathrm{P}<0.01,{ }^{* * *} \mathrm{P}<0.001$ vs. control. $\mathrm{H}_{2} \mathrm{O}_{2}$, hydrogen peroxide; $\mathrm{HOCl}$, hypochlorous acid; $\mathrm{ONOO}^{-}$, peroxynitrite; $\mathrm{GSH}$, glutathione.

50 single images were quantified per treatment condition. The intracellular GSH levels were calculated according to the formula: GSH level=mean fluorescence intensity (MFI) of bound GSH tracer/MFI of unbound GSH tracer.

Graphing and statistical analysis. Statistical analysis and graphing was performed using Prism 8.4 (GraphPad Software, Inc.). For statistical comparison between groups and controls, two-way analysis of variance with Dunnett's post hoc test was used. All experiments were performed $\geq 2$ times. $\mathrm{P}<0.05$ was considered to indicate a statistically significant difference.

\section{Results}

ROS decreases metabolic activity and viability in a dose-dependent manner. The present study aimed to identify the effect of different types of ROS on the viability and immunogenic properties of abdominal cancer cells. Colorectal (HT-29), pancreatic (Panc-01) and ovarian (SK-OV-3) cancer cells were exposed to either $\mathrm{H}_{2} \mathrm{O}_{2}, \mathrm{HOCl}$ or $\mathrm{ONOO}^{-}$at different doses. Following $2 \mathrm{~h}$ treatment with these ROS, cells were cultured and analyzed $24 \mathrm{~h}$ post-treatment (Fig. 1A). Compared with untreated control cells, oxidant concentrations between $0.1 \mu \mathrm{M}$ and $100 \mu \mathrm{M}$ did not significantly decrease cancer cell metabolic activity (Fig. 1B-D). At concentrations $>100 \mu \mathrm{M}, \mathrm{H}_{2} \mathrm{O}_{2}$ showed the lowest capability in decreasing the percentage of metabolically active tumor cells in the three cancer cell lines tested. $\mathrm{HOCl}$ exhibited the most substantial effects (Fig. 1B-D).

In order to analyze the cause of decreased metabolic activity, flow cytometry was used to quantify viable (DAPI ${ }^{-}$, active caspase-), early (DAPI-, active caspase ${ }^{+}$) and late apoptotic $\left(\mathrm{DAPI}^{+}\right.$, active caspase ${ }^{+}$, and necrotic $\left(\mathrm{DAPI}^{+}\right.$, active caspase $\left.{ }^{-}\right)$ tumor cells. A dose-dependent decrease in the number of viable cells was observed in all cell lines (Fig. 2A-C). In HT-29 cells, a significant decrease in the cell viability was found at

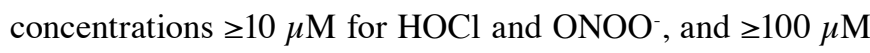
for $\mathrm{H}_{2} \mathrm{O}_{2}$ (Fig. 2A). In Panc-01 cells, a significant decrease in the number of viable cells was observed at $\geq 10 \mu \mathrm{M} \mathrm{ONOO}^{-}$, $\geq 100 \mu \mathrm{M}$ for $\mathrm{HOCl}$ and $\geq 1 \mathrm{mM}$ for $\mathrm{H}_{2} \mathrm{O}_{2}$ (Fig. 2B). Similar effects were also observed in SK-OV-3 cells; the number of viable cells significantly decreased at concentrations $\geq 1 \mathrm{mM}$ $\mathrm{H}_{2} \mathrm{O}_{2}$ and $\mathrm{ONOO}^{-}$, and $10 \mu \mathrm{M} \mathrm{HOCl}$ (Fig. 2C). Analysis of early and late apoptotic and necrotic cells (Fig. 2D, H and L) demonstrated the greatest extent of cell death occurred in HT-29 cells treated with $\mathrm{HOCl}$ (Fig. 2E-G). The fraction of necrotic cells remained small in all groups, except for HOCl-treated HT-29 and SK-OV-3 cells, and ONOO-treated Panc-01 cells at higher concentrations (Fig. 2F, N and K). In most experimental conditions, the fraction of late apoptotic cells was the largest of the dead cell populations. All oxidants induced notable toxicity in Panc-01 cells at high concentrations, while concentrations $\leq 10 \mu \mathrm{M}$ did not have a significant effect (Fig. 2I-K). HOCl-treated cells (10 mM) were not detectable (data not shown). SK-OV-3 cells exhibited notably elevated apoptotic cell death in all oxidative regimens (except for $1 \mathrm{mM} \mathrm{HOCl}$ with more necrotic cells); however, ONOOat concentrations $\geq 1 \mathrm{mM}$ failed to generate single-cell data because of aberrant toxicity (Fig. 2M-O).

ROS treatment affects metabolic activity and viability to a lesser extent in HaCaT cells than in cancer cells. In order to investigate the effect of oxidants in non-malignant cells, $\mathrm{HaCaT}$ keratinocytes were used as a control cell line. Similar to the tumor cells, a decrease in metabolic activity was observed (Fig. 3A). However, this was only notable at $1 \mathrm{mM}$. Moreover, viability data from flow cytometry suggested these cells to be less sensitive to oxidative treatment compared with cancer cells; a significant decrease in the number of viable cells was observed only at concentrations $>1 \mathrm{mM}$, except for $\mathrm{HOCl}$, which also exhibited a significant effect at 
A

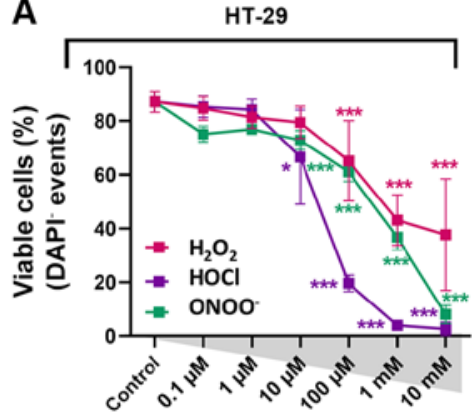

B

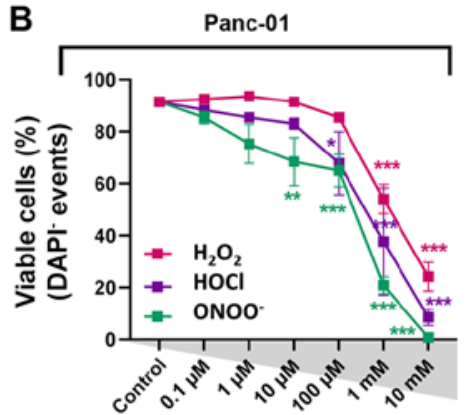

C

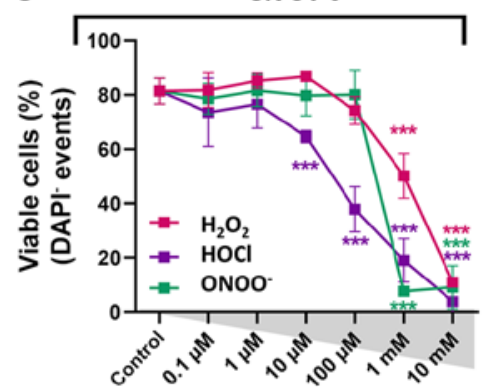

D

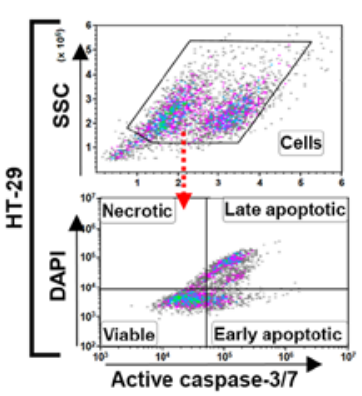

H

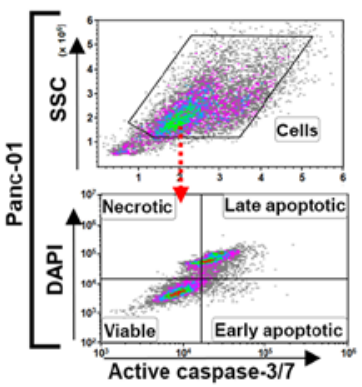

L

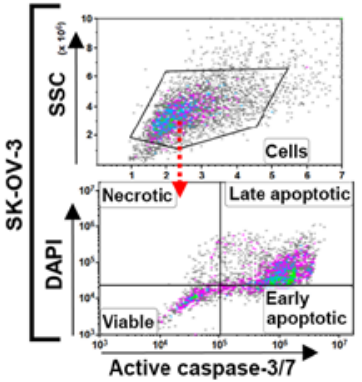

E

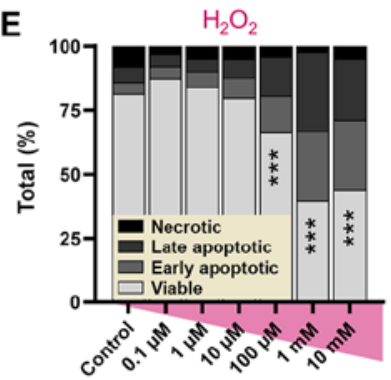

I $\mathrm{H}_{2} \mathrm{O}_{2}$ J

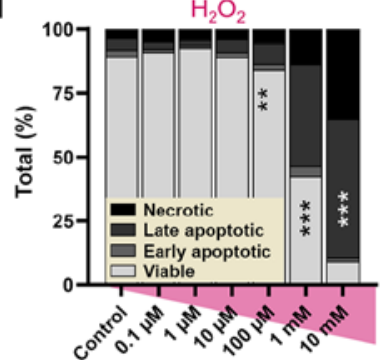

M

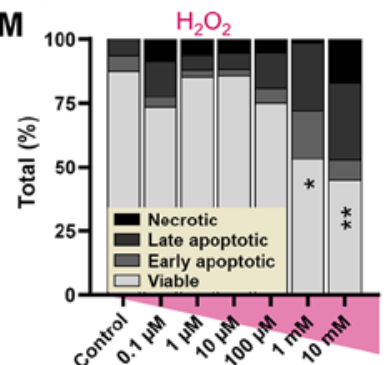

F

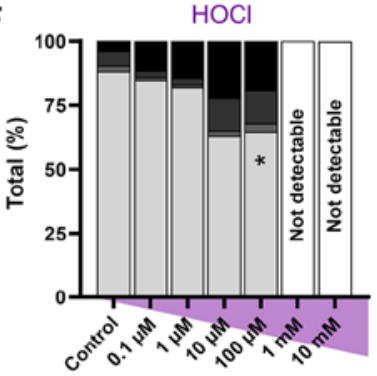

$\mathbf{J}$

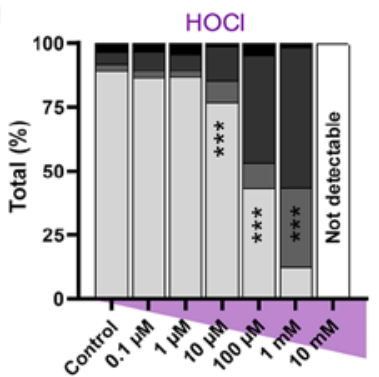

G

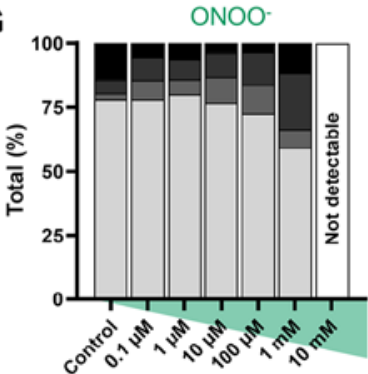

K

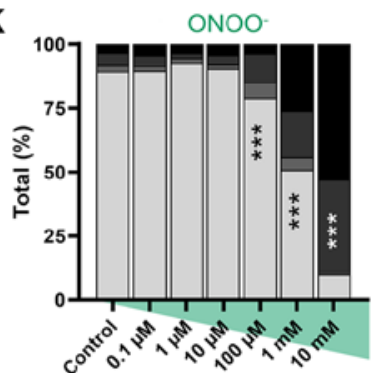

N

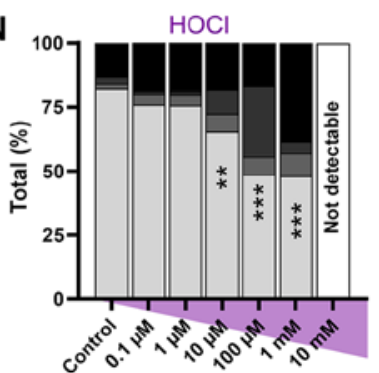

O

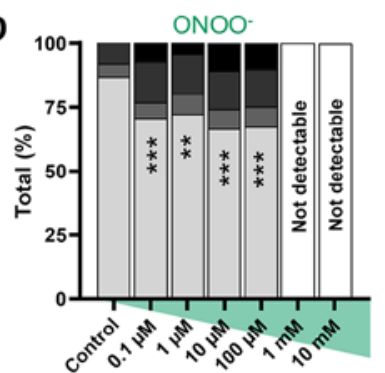

Figure 2. Oxidant treatment decreases viability of abdominal cancer cells in vitro. Percentage of viable (A) HT-29, (B) Panc-01 and (C) SK-OV-3 carcinoma cells at $24 \mathrm{~h}$ post-oxidant treatment. Data are presented as the mean \pm SEM. (D) Representative forward scatter and SSC and DAPI and active caspase 3/7 dot plots of HT-29 cells analyzed via flow cytometry. Cytotoxic effects of $(\mathrm{E}) \mathrm{H}_{2} \mathrm{O}_{2},(\mathrm{~F}) \mathrm{HOCl}$ and $(\mathrm{G}) \mathrm{ONOO}^{-}$in HT-29 cells. (H) Representative dot-plots of Panc-01 cells. Cytotoxic effects of (I) $\mathrm{H}_{2} \mathrm{O}_{2}$, (J) $\mathrm{HOCl}$ and (K) ONOO- in Panc-01 cells. (L) Representative dot-plots of SK-OV-3 cells. Cytotoxic effects of (M) $\mathrm{H}_{2} \mathrm{O}_{2}$, (N) $\mathrm{HOCl}$ and (O) ONOO in SK-OV-3 cells. Data are from five (A-C) and 2-3 (D-O) independent experiments. ${ }^{*} \mathrm{P}<0.05,{ }^{* * *} \mathrm{P}<0.01,{ }^{* * *} \mathrm{P}<0.001$ vs. control. $\mathrm{H}_{2} \mathrm{O}_{2}$, hydrogen peroxide; $\mathrm{HOCl}$, hypochlorous acid; $\mathrm{ONOO}^{-}$, peroxynitrite; SSC, side scatter.

$100 \mu \mathrm{M}$ (Fig. 3B). In order to identify the role of antioxidant defense, a GSH tracer was used to assess the relative amounts of GSH in the intracellular compartment (Fig. 3C). A slight but non-significant decrease in cytosolic GSH levels was observed at concentrations $\leq 10 \mu \mathrm{M}$ (Fig. 3D). Among the three types of ROS investigated, $\mathrm{H}_{2} \mathrm{O}_{2}$ exhibited the weakest effect on cytosolic GSH levels in HaCaT keratinocytes.

ROS exposure is concomitant with cytosolic and mitochondrial oxidation in cancer cells. Differences in oxidant capability to induce cell death were observed. High concentrations of $\mathrm{HOCl}$ and $\mathrm{ONOO}^{-}$exhibited the greatest toxicity and necrosis; $\mathrm{H}_{2} \mathrm{O}_{2}$ exhibited lower toxicity, and late apoptosis was observed at higher concentrations (Fig. 2). These differences indicated different underlying mechanisms for each ROS. In order to investigate this, intracellular oxidation was assessed. Cell pseudo-cytosolic DPC signal was used to segment the cell area via a software-based quantification tool (Fig. 4A) and the amount of bound and unbound GSH tracer, emitting at characteristic fluorescence emission spectra (Fig. 4B), inside the segmented cell region was quantified. Compared with untreated controls, $\geq 0.1 \mu \mathrm{M} \mathrm{H}_{2} \mathrm{O}_{2}$ and $\mathrm{HOCl}$ decreased intracellular GSH levels in HT-29 cancer 

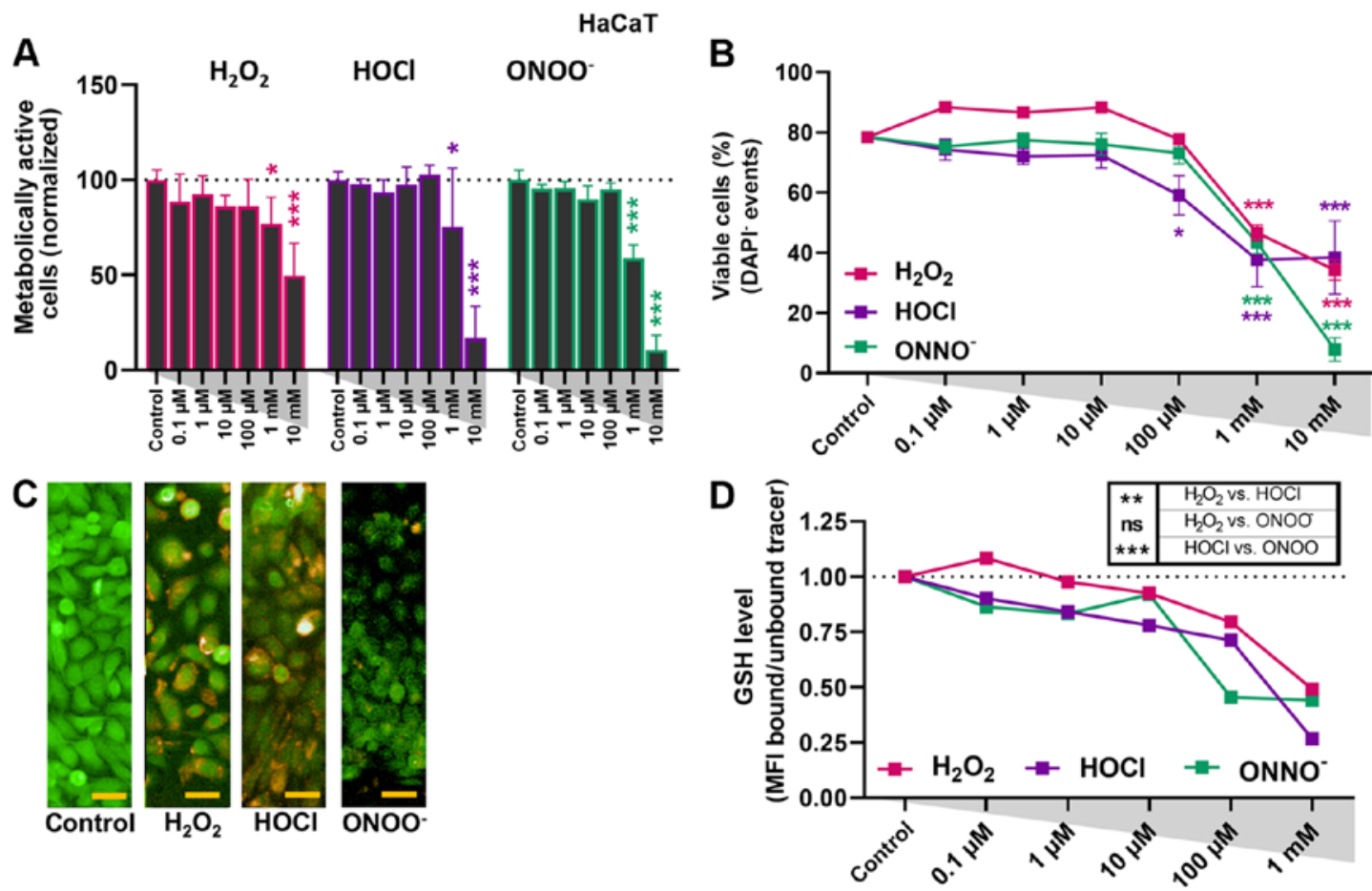

Figure 3. Oxidant treatment decreases the number of viable of HaCaT keratinocytes to a lesser extent than in abdominal cancer cells. (A) Percentage of metabolically active oxidant-treated HaCaT cells. Data are presented as the mean \pm SD. (B) Percentage of viable HaCaT cells at $24 \mathrm{~h}$ post-administration of oxidants as analyzed by flow cytometry. Data are presented as the mean \pm SEM. (C) Representative fluorescence microscopy images of both GSH fluorescence channels of HaCaT cells treated with $100 \mu \mathrm{M}$ oxidants. (D) Quantification of GSH level in HaCaT cells at 24 h, normalized to untreated control. Data are from three (B) and 2-4 (A, C and D) independent experiments. Scale bar, $20 \mu \mathrm{m}$. ${ }^{*} \mathrm{P}<0.05,{ }^{* * *} \mathrm{P}<0.001$ vs. control. $\mathrm{H}_{2} \mathrm{O}_{2}$, hydrogen peroxide; HOCl, hypochlorous acid; $\mathrm{ONOO}^{-}$, peroxynitrite; GSH, glutathione; MFI, mean fluorescence intensity.

cells (Fig. 4C and D). ONOO- only notably decreased GSH levels at $1 \mathrm{mM}$ (Fig. 4D). In Panc-01 cells, $\mathrm{ONOO}^{-}$and $\mathrm{H}_{2} \mathrm{O}_{2}$ decreased GSH levels at $\geq 0.1 \mu \mathrm{M}$, but to a lesser extent compared with $\mathrm{HOCl}$ at similar concentrations (Fig. 4F and G). Similar results were observed in SK-OV-3 cancer cells (Fig. 4I and J). Altogether, $\mathrm{HOCl}$ at low concentrations induced a notable consistent decrease in intracellular GSH levels in all three cancer cell lines, while non-malignant $\mathrm{HaCaT}$ keratinocytes were less affected at equimolar concentrations (Fig. 3D).

Following accumulation within the mitochondrial membrane, MTO fluorescence is increased upon oxidation via ROS (36). A notable increase in MTO fluorescence was observed with higher $\mathrm{HOCl}$ concentrations in all three cell lines (Fig. 4E, $\mathrm{H}$ and $\mathrm{K}$ ). By contrast, both $\mathrm{ONOO}^{-}$and $\mathrm{H}_{2} \mathrm{O}_{2}$ failed to induce notable mitochondrial oxidation, although a small increase was seen with $\mathrm{H}_{2} \mathrm{O}_{2}$ at higher concentrations. Among the three types of ROS compared at equimolar concentrations, $\mathrm{HOCl}$ showed the most potent oxidative and cytotoxic effects in the cancer cell lines investigated.

$\mathrm{HOCl}$ and $\mathrm{H}_{2} \mathrm{O}_{2}$ increase inflammatory surface molecule expression levels in cancer cells. In addition to cytotoxicity, the inflammatory and immune-stimulating potential of anti-cancer agents is of interest in clinical and pre-clinical research. Translocation of certain damage-associated molecular patterns (DAMPs), such as CRT (the chaperon of the endoplasmic reticulum), serves as an 'eat-me' signal to promote the phagocytosis of dying tumor cells, leading to the promotion of antitumor immunity (34). For HT-29 cells, the three types of ROS at concentrations $\geq 1 \mu \mathrm{M}$ increased expression levels of CRT on the membranes of viable cells (Fig. 5A and B). The most effective agent was $\mathrm{HOCl}$, which induced a 30 -fold increase in CRT at $10 \mathrm{mM}$ (Fig. 5B). In dead HT-29 cells, $\mathrm{H}_{2} \mathrm{O}_{2}$ was most effective and significantly increased CRT expression levels at concentrations $\geq 1 \mathrm{mM}$ (Fig. 5C). Changes in CRT expression levels in treated compared with untreated cells were smaller in dead compared with viable HT-29 cells. In viable and dead Panc-01 cells, $\mathrm{HOCl}$ did not significantly increase CRT expression levels. By contrast, both $\mathrm{ONOO}^{-}$and $\mathrm{H}_{2} \mathrm{O}_{2}$ at high concentrations promoted CRT levels, with $\mathrm{H}_{2} \mathrm{O}_{2}$ eliciting significantly elevated CRT levels, especially in dead cells (Fig. 5D-F). In viable SK-OV-3 cells, upregulation of CRT on the membrane was observed in a dose-dependent manner for all oxidative treatment regimens (Fig. 5G and $\mathrm{H}$ ). However, this was only significant at $10 \mathrm{mM} \mathrm{HOCl}^{-}$and $\mathrm{ONOO}^{-}$. In the fraction of dead SK-OV-3 cells, significant CRT upregulation was observed at $\mathrm{H}_{2} \mathrm{O}_{2}$ concentrations $\geq 1 \mathrm{mM}$ (Fig. 5I). Danger signals, such HSP70 and HSP90 (Fig. 5J and K), notably increased in HOCl-treated HT-29 and $\mathrm{H}_{2} \mathrm{O}_{2}$-treated Panc-01 cells. In dead SK-OV-3 cells, a notable increase in HSP90 was observed with all three types of ROS.

\section{Discussion}

In order to investigate ROS as a putative supplement to lavage treatment of $\mathrm{PC}$, the present study assessed toxicity and immune-relevant surface marker expression levels in three human abdominal cancer cell lines (HT-29, Panc-01 and SK-OV-3) following exposure to $\mathrm{H}_{2} \mathrm{O}_{2}$, $\mathrm{HOCl}$ or ONOOCancer cells were more sensitive to ROS-induced toxicity compared with non-malignant $\mathrm{HaCaT}$ keratinocytes and exhibited increased levels of immuno-relevant surface markers. At 
A
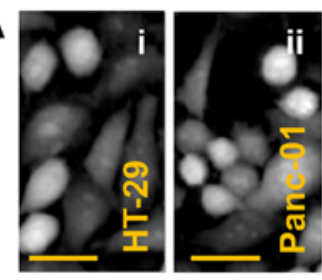

C

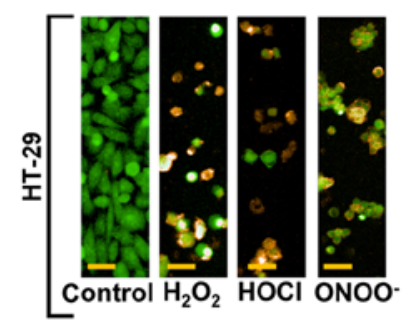

F

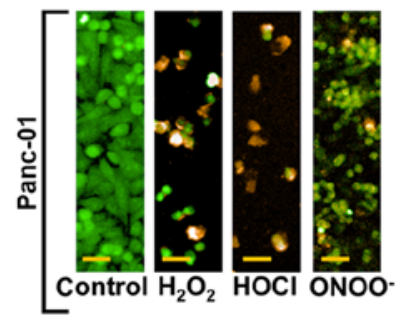

I

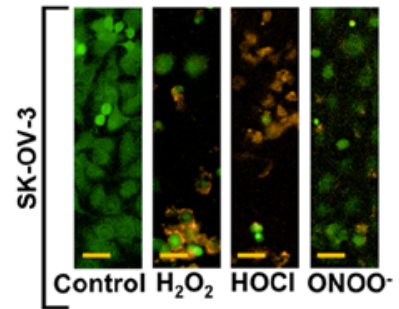

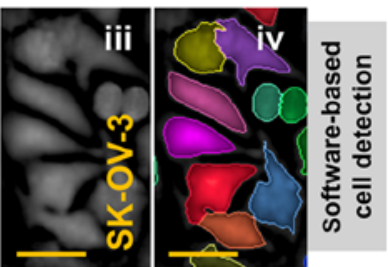

D

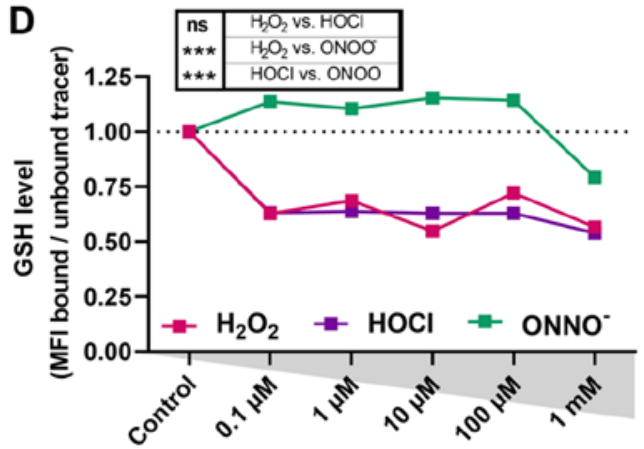

G

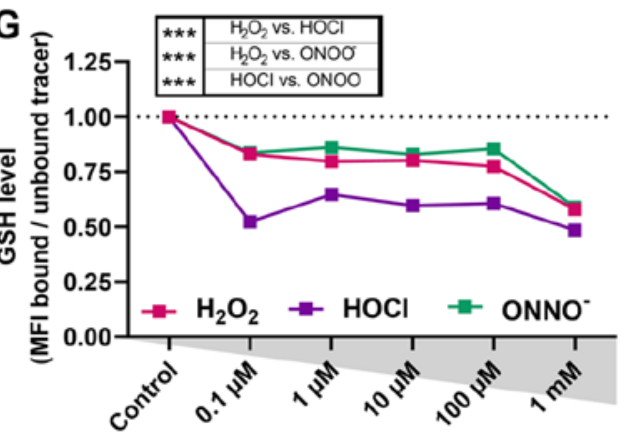

$\mathbf{J}$

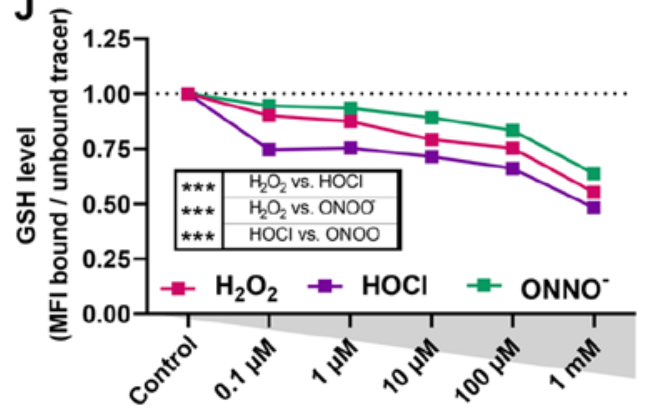

B
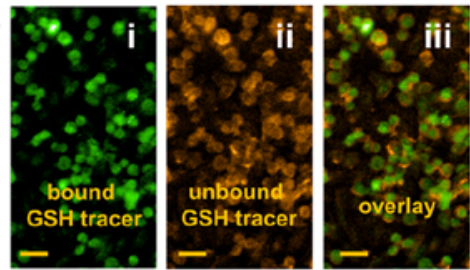

E

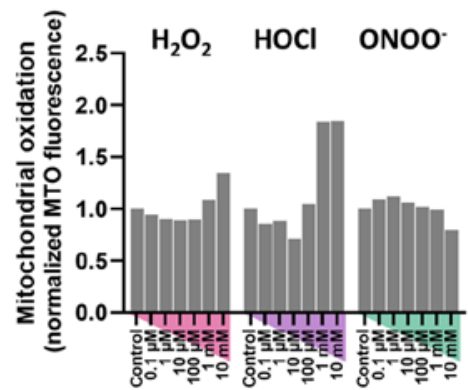

$\mathrm{H}$

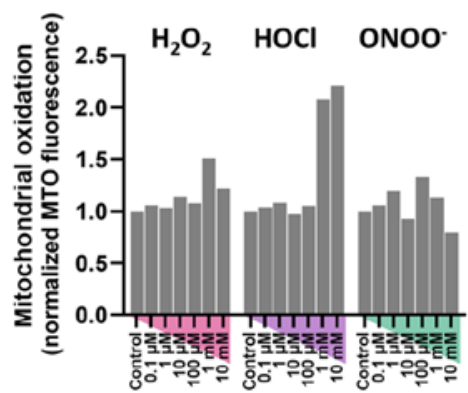

K

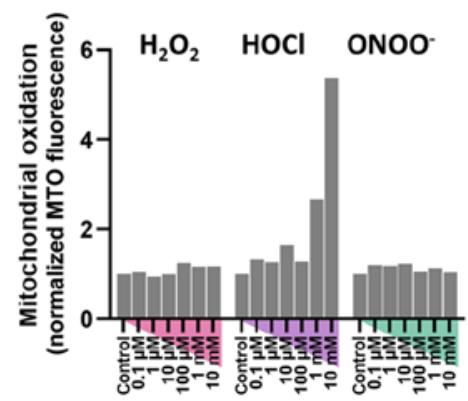

Figure 4. Oxidant treatment decreases intracellular GSH and increases mitochondrial ROS in cancer cells. (A) Representative images of the pseudocytosolic signal of i) HT-29, ii) Panc-01 and iii) SK-OV-3 carcinoma cells, with iv) representative software-based cell segmentation for subsequent quantitative analysis. (B) Representative images of cancer cells with i) bound and ii) unbound GSH tracer and iii) and overlay. (C) Representative images of GSH fluorescence channels for HT-29 cells in the presence or absence of $100 \mu \mathrm{M}$ oxidants. (D) Quantification of GSH levels of HT-29 cells at $24 \mathrm{~h}$ (E) Quantification of MTO fluorescence of HT-29 cells. (F) Representative images of GSH fluorescence channels for Panc-01 cells in the presence or absence of $100 \mu \mathrm{M}$ oxidants. (G) Quantification of GSH levels of Panc-01 cells at $24 \mathrm{~h}$. (H) Quantification of MTO fluorescence of Panc-01 cells (I) Representative images of GSH fluorescence channels for SK-OV-3 cells in the presence or absence of $100 \mu \mathrm{M}$ oxidants. (J) Quantification of GSH levels in SK-OV-3 cells at $24 \mathrm{~h}$. (K) Quantification of MTO fluorescence of SK-OV-3 cells. Scale bar, $30 \mu \mathrm{m}$. Data are representative of two independent experiments with $\geq 50$ fields of view per treatment condition, concentration and cell type. All data are normalized to untreated control. $\mathrm{H}_{2} \mathrm{O}_{2}$, hydrogen peroxide; $\mathrm{HOCl}$, hypochlorous acid; $\mathrm{ONOO}^{-}$, peroxynitrite; GSH, glutathione; ROS, reactive oxygen species; MTO, mitotracker orange; MFI, mean fluorescence intensity.

equimolar concentrations, $\mathrm{HOCl}$ appeared to be a particularly promising candidate for adjuvant ROS therapy.

The three types of ROS notably decreased the viability and metabolic activity in all three cancer cell lines, especially at concentrations $\geq 100 \mu \mathrm{M}$. Mechanistically, ROS may act via direct oxidation of intracellular proteins or nucleic acids, which promotes regulated cell death and senescence (37-39), as well as through ROS/reactive nitrogen species-redox signaling events that drive apoptosis via downstream signaling (40-42).
At higher ROS concentrations, tumor cells were rendered inactivate but were not eliminated completely. This has previously been observed in $\mathrm{H}_{2} \mathrm{O}_{2}$-treated colorectal cancer cells (43), and similar effects have been detected in cells with functional ATM enzymes exposed to ONOO- (44), as well as $\mathrm{HOCl}$ in diabetes and liver disease (45). Here, $\mathrm{HOCl}$ and $\mathrm{ONOO}^{-}$were slightly more effective than $\mathrm{H}_{2} \mathrm{O}_{2}$ in decreasing the number of viable cancer cells, indicating different mechanisms of action for these molecules. It was previously shown 

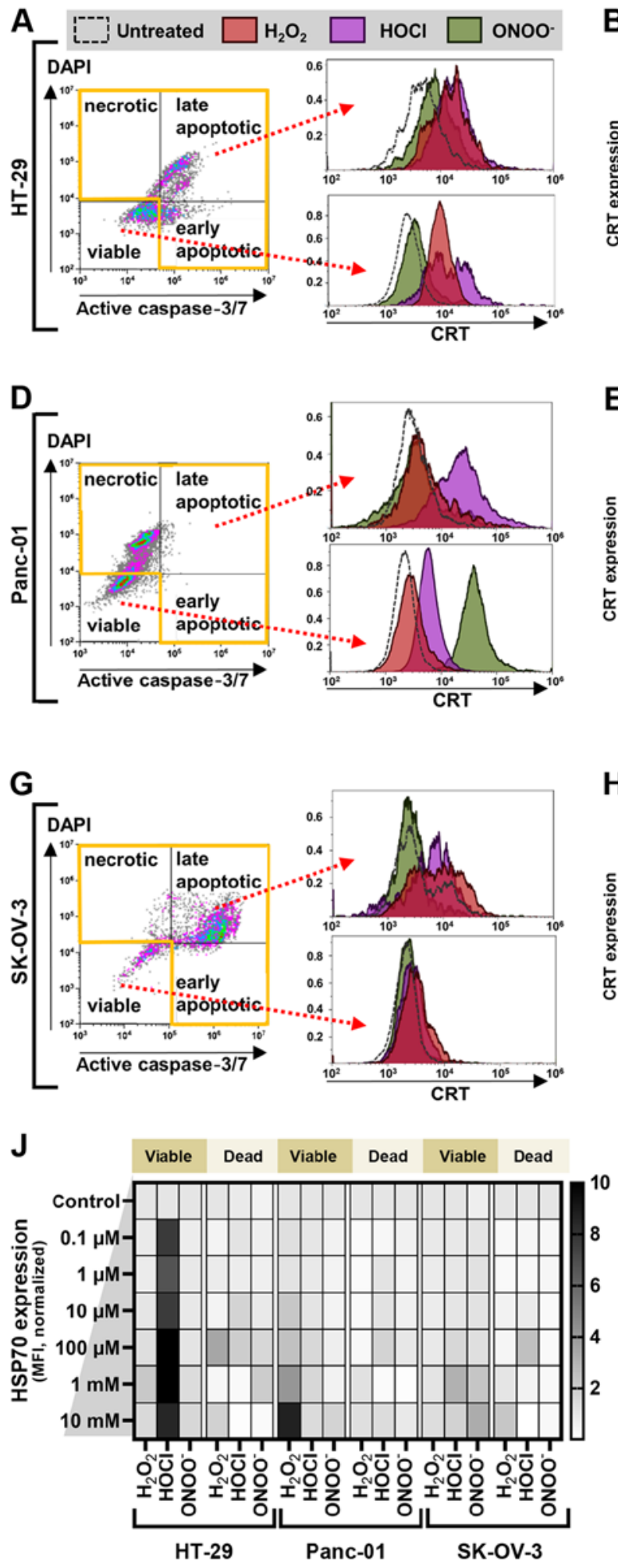
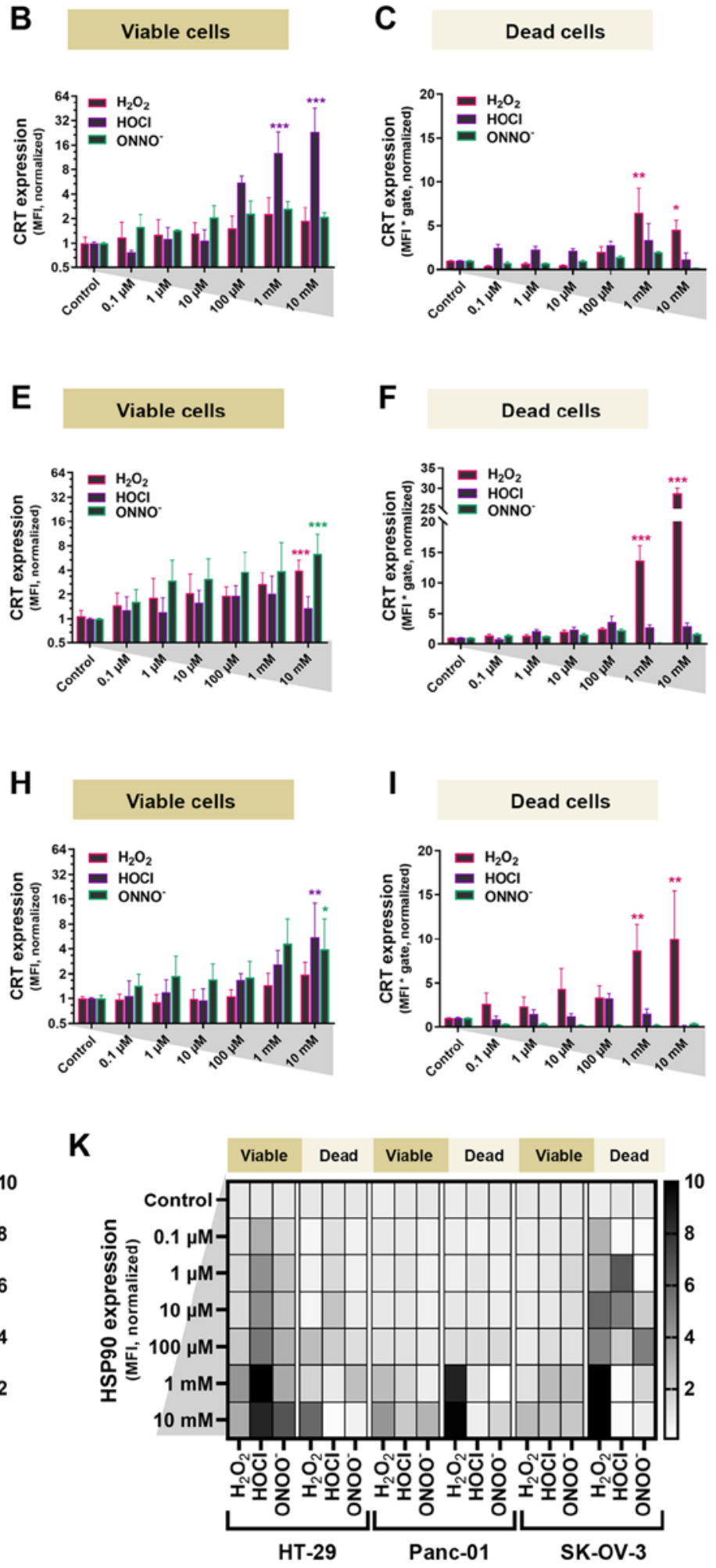

Figure 5. Oxidant treatment induces CRT expression in abdominal cancer cells. (A) Representative live-dead cell gating and overlay of CRT fluorescence in

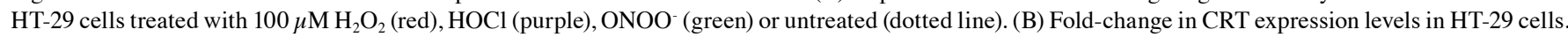
(C) Quantification of CRT expression levels in dead HT-29 cells. (D) Representative live-dead cell gating and overlay of CRT fluorescence in Panc-01 cells treated with $100 \mu \mathrm{M}$ oxidants. (E) Fold-change in CRT expression levels in viable Panc-01 cells. (F) Quantification of CRT expression in dead Panc-01 cells. (G) Representative live-dead cell gating and overlay of CRT fluorescence in SK-OV-3 cells treated with $100 \mu \mathrm{M}$ oxidants. (H) Fold-change of CRT expression levels in viable SK-OV-3 cells. (I) Quantification of CRT expression levels in dead SK-OV-3 cells. Heat map of expression levels of (J) HSP70 and (K) HSP90 in viable and dead cancer cells at $24 \mathrm{~h}$. Data are from 3-4 independent experiments and are presented as the mean \pm SD. All data are normalized to untreated controls. ${ }^{*} \mathrm{P}<0.05,{ }^{* *} \mathrm{P}<0.01,{ }^{* * *} \mathrm{P}<0.001$ vs. control. $\mathrm{H}_{2} \mathrm{O}_{2}$, hydrogen peroxide; HOCl, hypochlorous acid; ONOO , peroxynitrite; CRT, calreticulin; HSP, heat-shock protein; MFI, mean fluorescence intensity.

that knockdown of the ROS-generating enzymes NADPH oxidase 1 (NOX1) and dual oxidase 1 in cancer cells prevents apoptosis following exposure to $\mathrm{H}_{2} \mathrm{O}_{2}$ (46). By contrast, knockdown of both NOX1 and inducible nitric oxide synthase 
is required to abrogate $\mathrm{HOCl}$-mediated apoptosis (47). These results suggest an underlying self-amplification mechanism of intracellular and membrane-generated ROS that contributes to ROS-induced cancer cell death. Moreover, $\mathrm{ONOO}^{-}$and $\mathrm{H}_{2} \mathrm{O}_{2}$ have been implicated in PI3K/Akt-mediated activation of the nuclear factor erythroid 2-related factor 2 pathway and microtubule-associated protein $1 \mathrm{~A} / 1 \mathrm{~B}$-light chain 3 , indicating a role of antioxidant defense and autophagy in ROS-mediated cell death $(48,49)$. $\mathrm{HOCl}$ is also produced endogenously by activated neutrophils via myeloperoxidase during inflammation to promote anti-microbial effects (50). In addition, $\mathrm{HOCl}$ promotes tumor cell death via several mechanisms, such as as the enhancement of antigen presentation and uptake, as well as the induction of an anti-tumor response driven by cytotoxic $\mathrm{T}$ cells (51).

The oxidation of cancer cells was here demonstrated by decreased intracellular levels of the antioxidant GSH. The availability of GSH provides information on the cellular antioxidant defense capacity and is associated with redox signaling processes (52). In the present study, non-malignant HaCaT keratinocytes showed the lowest overall decrease in GSH and the highest viability when exposed to different types of ROS at equimolar concentrations compared with the cancer cell lines tested. This may be because cancer cells naturally exhibit high levels of endogenous oxidative stress, which leads to increased susceptibility to ROS-induced cell death $(14,53)$. The greatest decrease in intracellular GSH levels was observed following the administration of $\mathrm{HOCl}$ and $\mathrm{H}_{2} \mathrm{O}_{2}$, compared with $\mathrm{ONOO}^{-}$. This may be explained by the lower affinity of the latter to $\mathrm{GSH}$, the generation of S-nitroglutathione and the high affinity between $\mathrm{ONOO}^{-}$and $\mathrm{CO}_{2}$ in reactions at high-rate constants $(54,55)$. Here, $\mathrm{ONOO}^{-}$was also shown to have the lowest capacity to oxidize mitochondria. These findings are consistent with a previous study (46) that suggested $\mathrm{HOCl}$ to be of particular importance in the induction of cell death due to its ability of auto-propagating ROS formation through mitochondria.

One of the critical hallmarks of antitumor immune responses is the induction of ICD via increased danger signals (such as DAMPs), including the chaperon of the endoplasmic reticulum, CRT, on the tumor cell membrane (34,56). CRT can act as a danger and 'eat-me' signal when recognized by innate immune cells, such as dendritic cells (57). Other DAMPs include HSP70 and HSP90 as markers for cellular stress, leading to their upregulation and translocation to the cell membrane (58). ICD is associated with the upregulation of these molecules, as previously shown using antitumor agents tested for their immunogenicity in mice (34). In the present study, all types of ROS tested increased the levels of CRT on tumor cells. Specific responses, however, were dependent on the cell type and oxidant. $\mathrm{HOCl}$, and to a lesser extent $\mathrm{ONOO}^{-}$, gave promising results in at least two of the three tumor cell lines investigated by enhancing the presentation of pro-immunogenic molecules on their membrane. Exposure to these ROS results in the formation of DAMPs, which promote antitumor immunity $(59,60)$, although the present study did not directly investigate the immunological consequences. Increased CRT levels were also observed in dead tumor cells following treatment with high concentrations of $\mathrm{H}_{2} \mathrm{O}_{2} \cdot \mathrm{H}_{2} \mathrm{O}_{2}$ was previously found to promote a pro-immunogenic phenotype in murine colorectal cancer cells in vitro, as well as in mice with PC (37); this was concomitant with enhanced immune infiltration and activation. Moreover, ROS are capable of shaping activation profiles in human myeloid cells $(37,61,62)$. ICD was previously observed with photodynamic therapy, which generates singlet oxygen to promote cellular oxidation $(63,64)$, supporting the findings of mitochondrial oxidation and decreased cellular GSH levels in the present study. A previous report noted that $\mathrm{ONOO}^{-}$affects major histocompatibility complex-I recognition by $\mathrm{T}$ lymphocytes (65).

The present study identified $\mathrm{HOCl}$ as the most promising candidate in terms of toxicity and induction of immunogenic danger molecules (such as CRT) in cancer cells. $\mathrm{HOCl}$ was previously shown to enhance the immunogenicity of colorectal cancer cells in vivo, prevent distant metastasis of human melanoma cells, and alter antigen-presenting machinery and the cross-priming of tumor material (66-70). This makes $\mathrm{HOCl}$ a promising candidate as an adjuvant in peritoneal cancer therapy outside the current vaccination strategies against ovarian cancer employed with this type of ROS (71).

Treatment with $\mathrm{H}_{2} \mathrm{O}_{2}$, $\mathrm{HOCl}$ and $\mathrm{ONOO}^{-}$led to intracellular oxidation and notable toxicity in all abdominal cancer cell lines tested. Non-malignant HaCaT keratinocytes were less affected compared with cancer cells, suggesting a degree of specificity to the ROS-induced cell death. Treatment of cancer cells with these ROS also led to an upregulation of molecules associated with activation of immune cells. $\mathrm{HOCl}$ was the most promising therapeutic candidate, as it exhibited the greatest ability to inactivate cancer cells and upregulate danger molecules known to promote antitumor immunity. Future studies may extend this concept to provide novel therapeutic avenues in the treatment of PC.

\section{Acknowledgements}

The authors would like to thank Felix Niessner (Leibniz Institute for Plasma Science and Technology, INP Greifswald) for technical support.

\section{Funding}

The present study was funded by the German Federal Ministry of Education and Research (grant nos. 03Z22DN11 and 03Z22Di1) and Gerhard-Domagk Foundation (Greifswald, Germany).

\section{Availability of data and materials}

The datasets used and/or analyzed during the current study are available from the corresponding author on reasonable request.

\section{Authors' contributions}

EF and SB designed the study. LM performed the experiments. EF, LM and SB confirm the authenticity of all the raw data. EF, LM, MBS and SB analyzed the data, prepared the figures and wrote and reviewed the manuscript. EF, LM, MBS and SB read and approved the final manuscript. 


\section{Ethics approval and consent to participate}

Not applicable.

\section{Patient consent for publication}

Not applicable.

\section{Competing interests}

The authors declare they have no competing interests.

\section{References}

1. Dakwar GR, Shariati M, Willaert W, Ceelen W, De Smedt SC and Remaut K: Nanomedicine-based intraperitoneal therapy for the treatment of peritoneal carcinomatosis-mission possible? Adv Drug Deliv Rev 108: 13-24, 2017.

2. Piso P and Arnold D: Multimodal treatment approaches for peritoneal carcinosis in colorectal cancer. Dtsch Arztebl Int 108: 802-808, 2011

3. Oettle H, Neuhaus P, Hochhaus A, Hartmann JT, Gellert K, Ridwelski K, Niedergethmann M, Zülke C, Fahlke J, Arning MB, et al: Adjuvant chemotherapy with gemcitabine and long-term outcomes among patients with resected pancreatic cancer: The CONKO-001 randomized trial. JAMA 310 1473-1481, 2013.

4. Esposito I, Kleeff J, Bergmann F, Reiser C, Herpel E, Friess H, Schirmacher P and Büchler MW: Most pancreatic cancer resections are R1 resections. Ann Surg Oncol 15: 1651-1660, 2008.

5. Shida D, Tsukamoto S, Ochiai H and Kanemitsu Y: Long-term outcomes after R0 resection of synchronous peritoneal metastasis from colorectal cancer without cytoreductive surgery or hyperthermic intraperitoneal chemotherapy. Ann Surg Oncol 25 $173-178,2018$.

6. Tentes AA, Pallas N, Karamveri C, Kyziridis D and Hristakis C: Cytoreduction and HIPEC for peritoneal carcinomatosis of pancreatic cancer. J BUON 23: 482-487, 2018.

7. Jayson GC, Kohn EC, Kitchener HC and Ledermann JA: Ovarian cancer. Lancet 384: 1376-1388, 2014.

8. Pelz JO, Chua TC, Esquivel J, Stojadinovic A, Doerfer J, Morris DL, Maeder U, Germer CT and Kerscher AG: Evaluation of best supportive care and systemic chemotherapy as treatment stratified according to the retrospective peritoneal surface disease severity score (PSDSS) for peritoneal carcinomatosis of colorectal origin. BMC Cancer 10: 689, 2010.

9. Goéré D, Souadka A, Faron M, Cloutier AS, Viana B, Honoré C, Dumont F and Elias D: Extent of colorectal peritoneal carcinomatosis: Attempt to define a threshold above which HIPEC does not offer survival benefit: A comparative study. Ann Surg Oncol 22: 2958-2964, 2015.

10. Solass W, Kerb R, Mürdter T, Giger-Pabst U, Strumberg D, Tempfer C,Zieren J, Schwab M and Reymond MA: Intraperitoneal chemotherapy of peritoneal carcinomatosis using pressurized aerosol as an alternative to liquid solution: First evidence for efficacy. Ann Surg Oncol 21: 553-559, 2014.

11. Pinto A and Pocard M: Photodynamic therapy and photothermal therapy for the treatment of peritoneal metastasis: A systematic review. Pleura Peritoneum 3: 20180124, 2018.

12. Farooqi AA, Li KT, Fayyaz S, Chang YT, Ismail M, Liaw CC, Yuan SS, Tang JY and Chang HW: Anticancer drugs for the modulation of endoplasmic reticulum stress and oxidative stress. Tumour Biol 36: 5743-5752, 2015.

13. Galadari S, Rahman A, Pallichankandy S and Thayyullathil F: Reactive oxygen species and cancer paradox: To promote or to suppress? Free Radic Biol Med 104: 144-164, 2017.

14. Glasauer A and Chandel NS: Targeting antioxidants for cancer therapy. Biochem Pharmacol 92: 90-101, 2014.

15. Gorrini C,Harris IS and Mak TW: Modulation of oxidative stress as an anticancer strategy. Nat Rev Drug Discov 12: 931-947, 2013.

16. Brigger I, Dubernet $C$ and Couvreur P: Nanoparticles in cancer therapy and diagnosis. Adv Drug Del Rev 64: 24-36, 2012.

17. Manshian BB, Poelmans J, Saini S, Pokhrel S, Grez JJ, Himmelreich U, Mädler L and Soenen SJ: Nanoparticle-induced inflammation can increase tumor malignancy. Acta Biomater 68: 99-112, 2018
18. Manke A, Wang L and Rojanasakul Y: Mechanisms of nanoparticle-induced oxidative stress and toxicity. Biomed Res Int 2013: 942916, 2013.

19. Hou JT, Wang B, Zhang Y, Cui B, Cao X, Zhang M, Ye Y and Wang S: Observation of peroxynitrite overproduction in cells during 5-fluorouracil treatment via a ratiometric fluorescent probe. Chem Commun (Camb) 56: 2759-2762, 2020.

20. Kepp O, Menger L, Vacchelli E, Locher C, Adjemian S, Yamazaki T, Martins I, Sukkurwala AQ, Michaud M, Senovilla L, et al: Crosstalk between ER stress and immunogenic cell death. Cytokine Growth Factor Rev 24: 311-318, 2013.

21. Agostinis P, Berg K, Cengel KA, Foster TH, Girotti AW, Gollnick SO, Hahn SM, Hamblin MR, Juzeniene A, Kessel D, et al: Photodynamic therapy of cancer: An update. CA Cancer J Clin 61: 250-281, 2011.

22. Garg AD and Agostinis P: ER stress, autophagy and immunogenic cell death in photodynamic therapy-induced anti-cancer immune responses. Photochem Photobiol Sci 13: 474-487, 2014.

23. Bekeschus S, Schmidt A, Niessner F, Gerling T, Weltmann KD and Wende K: Basic research in plasma medicine-a throughput approach from liquids to cells. J Vis Exp: 56331, 2017.

24. Jablonowski H, Santos Sousa J, Weltmann KD, Wende K and Reuter S: Quantification of the ozone and singlet delta oxygen produced in gas and liquid phases by a non-thermal atmospheric plasma with relevance for medical treatment. Sci Rep 8: 12195, 2018.

25. Bekeschus S, Wende K, Hefny MM, Rödder K, Jablonowski H, Schmidt A, Woedtke TV, Weltmann KD and Benedikt J: Oxygen atoms are critical in rendering THP-1 leukaemia cells susceptible to cold physical plasma-induced apoptosis. Sci Rep 7: 2791, 2017.

26. Bekeschus S, Clemen R, Nießner F, Sagwal SK, Freund E and Schmidt A: Medical gas plasma jet technology targets murine melanoma in an immunogenic fashion. Adv Sci (Weinh) 7: 1903438,2020

27. Lin A, Gorbanev Y, De Backer J, Van Loenhout J, Van Boxem W, Lemière F, Cos $\mathrm{P}$, Dewilde $\mathrm{S}$, Smits $\mathrm{E}$ and Bogaerts $\mathrm{A}$ : Non-thermal plasma as a unique delivery system of short-lived reactive oxygen and nitrogen species for immunogenic cell death in melanoma cells. Adv Sci (Weinh) 6: 1802062, 2019.

28. Bekeschus S, Clemena R and Metelmann HR: Potentiating anti-tumor immunity with physical plasma. Clin Plas Med 12: $17-22,2018$

29. Garg AD, Nowis D, Golab J, Vandenabeele P, Krysko DV and Agostinis P: Immunogenic cell death, DAMPs and anticancer therapeutics: An emerging amalgamation. Biochim Biophys Acta 1805: 53-71, 2010.

30. Khalili M, Daniels L, Lin A, Krebs FC, Snook AE, Bekeschus S, Bowne WB and Miller V: Non-thermal plasma-induced immunogenic cell death in cancer: A topical review. J Phys D Appl Phys 52: 423001, 2019

31. Galluzzi L, Buqué A, Kepp O, Zitvogel L and Kroemer G: Immunogenic cell death in cancer and infectious disease. Nat Rev Immunol 17: 97-111, 2017.

32. Ledford H, Else $\mathrm{H}$ and Warren M: Cancer immunologists scoop medicine nobel prize. Nature 562: 20-21, 2018.

33. Leebmann $\mathrm{H}$ and Piso P: PIPAC and HIPEC-competing or supplementary therapeutic procedures for peritoneal metastases. Chirurg 89: 693-698, 2018 (In German).

34. Obeid M, Tesniere A, Ghiringhelli F, Fimia GM, Apetoh L, Perfettini JL, Castedo M, Mignot G, Panaretakis T, Casares N, et al: Calreticulin exposure dictates the immunogenicity of cancer cell death. Nat Med 13: 54-61, 2007.

35. Freund E and Bekeschus S: Gas plasma-oxidized liquids for cancer treatment: Pre-clinical relevance, immuno-oncology, and clinical obstacles. IEEE Trans Radiat Plasma Med Sci: 1-1, 2020.

36. Kholmukhamedov A, Schwartz JM and Lemasters JJ: Isolated mitochondria infusion mitigates ischemia-reperfusion injury of the liver in rats: Mitotracker probes and mitochondrial membrane potential. Shock 39: 543, 2013.

37. Freund E, Liedtke KR, van der Linde J, Metelmann HR, Heidecke CD, Partecke LI and Bekeschus S: Physical plasma-treated saline promotes an immunogenic phenotype in CT26 colon cancer cells in vitro and in vivo. Sci Rep 9: 634, 2019.

38. Yamao T, Yamashita YI, Yamamura K, Nakao Y, Tsukamoto M, Nakagawa S, Okabe H, Hayashi $\mathrm{H}$, Imai $\mathrm{K}$ and Baba $\mathrm{H}$ : Cellular senescence, represented by expression of caveolin-1, in cancer-associated fibroblasts promotes tumor invasion in pancreatic cancer. Ann Surg Oncol 26: 1552-1559, 2019. 
39. Waris $G$ and Ahsan H: Reactive oxygen species: Role in the development of cancer and various chronic conditions. J Carcinog 5: 14, 2006.

40. Valko M, Leibfritz D, Moncol J, Cronin MT, Mazur M and Telser J: Free radicals and antioxidants in normal physiological functions and human disease. Int J Biochem Cell Biol 39: 44-84, 2007.

41. Zhang J, Wang X, Vikash V, Ye Q, Wu D, Liu Y and Dong W: ROS and ROS-mediated cellular signaling. Oxid Med Cell Longev 2016: 4350965, 2016.

42. Yu FX and Guan KL: The hippo pathway: Regulators and regulations. Genes Dev 27: 355-371, 2013.

43. Freund E, Liedtke KR, Miebach L, Wende K, Heidecke A, Kaushik NK, Choi EH, Partecke LI and Bekeschus S: Identification of two kinase inhibitors with synergistic toxicity with low-dose hydrogen peroxide in colorectal cancer cells in vitro. Cancers (Basel) 12: 122, 2020.

44. Bagheri M, Nair RR, Singh KK and Saini DK: ATM- ROS-iNOS axis regulates nitric oxide mediated cellular senescence. Biochim Biophys Acta Mol Cell Res 1864: 177-190, 2017.

45. Acosta JC, Banito A, Wuestefeld T, Georgilis A, Janich P, Morton JP, Athineos D, Kang TW, Lasitschka F, Andrulis M, et al A complex secretory program orchestrated by the inflammasome controls paracrine senescence. Nat Cell Biol 15: 978-990, 2013.

46. Weyemi U, Redon CE, Parekh PR, Dupuy C and Bonner WM: NADPH oxidases NOXs and DUOXs as putative targets for cancer therapy. Anticancer Agents Med Chem 13: 502-514, 2013.

47. Bauer G: Central signaling elements of intercellular reactive oxygen/nitrogen species-dependent induction of apoptosis in malignant cells. Anticancer Res 37: 499-513, 2017.

48. Navarro-Yepes J, Burns M, Anandhan A, Khalimonchuk O, del Razo LM, Quintanilla-Vega B, Pappa A, Panayiotidis MI and Franco R: Oxidative stress, redox signaling, and autophagy: Cell death versus survival. Antioxid Redox Signal 21: 66-85, 2014.

49. Speckmann B, Steinbrenner H, Grune T and Klotz LO Peroxynitrite: From interception to signaling. Arch Biochem Biophys 595: 153-160, 2016.

50. Perkins A, Tudorica DA, Amieva MR, Remington SJ and Guillemin K: Helicobacter pylori senses bleach ( $\mathrm{HOCl}$ ) as a chemoattractant using a cytosolic chemoreceptor. PLoS Biol 17: e3000395, 2019

51. Vandenberk L, Belmans J, Van Woensel M, Riva M and Van Gool SW: Exploiting the immunogenic potential of cancer cells for improved dendritic cell vaccines. Front Immunol 6: 663, 2016.

52. Bansal A and Simon MC: Glutathione metabolism in cancer progression and treatment resistance. J Cell Biol 217: 2291-2298, 2018.

53. Acharya A, Das I, Chandhok D and Saha T: Redox regulation in cancer: A double-edged sword with therapeutic potential. Oxid Med Cell Longev 3: 23-34, 2010.

54. Balazy M, Kaminski PM, Mao K, Tan J and Wolin MS S-nitroglutathione, a product of the reaction between peroxynitrite and glutathione that generates nitric oxide. J Biol Chem 273: 32009-32015, 1998.

55. Padmaja S, Squadrito GL and Pryor WA: Inactivation of glutathione peroxidase by peroxynitrite. Arch Biochem Biophys 349: $1-6,1998$

56. Tesniere A, Apetoh L, Ghiringhelli F, Joza N, Panaretakis T, Kepp O, Schlemmer F, Zitvogel L and Kroemer G: Immunogenic cancer cell death: A key-lock paradigm. Curr Opinc Immunol 20 504-511, 2008
57. Fucikova J, Kasikova L, Truxova I, Laco J, Skapa P, Ryska A and Spisek R: Relevance of the chaperone-like protein calreticulin for the biological behavior and clinical outcome of cancer. Immunol Lett 193: 25-34, 2018

58. Adkins I, Sadilkova L, Hradilova N, Tomala J, Kovar M and Spisek R: Severe, but not mild heat-shock treatment induces immunogenic cell death in cancer cells. Oncoimmunology 6: e1311433, 2017.

59. Panaretakis T, Kepp O, Brockmeier U, Tesniere A, Bjorklund AC, Chapman DC, Durchschlag M, Joza N, Pierron G, van Endert P, et al: Mechanisms of pre-apoptotic calreticulin exposure in immunogenic cell death. EMBO J 28: 578-590, 2009.

60. Gordon S: The role of the macrophage in immune regulation. Res Immunol 149: 685-688, 1998

61. Liedtke KR, Freund E, Hackbartha C, Heideckea CD Parteckea LI and Bekeschus S: A myeloid and lymphoid infiltrate in murine pancreatic tumors exposed to plasma-treated medium. Clin Plas Med 11: 10-17, 2018.

62. Freund E, Moritz J, Stope M, Seebauer C, Schmidt A and Bekeschus S: Plasma-derived reactive species shape a differentiation profile in human monocytes. Appl Sci 9: 2530, 2019.

63. Panzarini E, Inguscio V and Dini L: Immunogenic cell death: Can it be exploited in photodynamic therapy for cancer? Biomed Res Int 2013: 482160, 2013.

64. Garg AD, Krysko DV, Vandenabeele P and Agostinis P: Hypericin-based photodynamic therapy induces surface exposure of damage-associated molecular patterns like HSP70 and calreticulin. Cancer Immunol Immunother 61: 215-221, 2012

65. Tcyganov E and Gabrilovich DI: Peroxynitrite affects MHC I peptide repertoire presented on tumor cells and impedes the efficacy of antitumor cytotoxic T-lymphocytes. J Immunol 202 (Suppl 1): S137.12, 2019.

66. Piskounova E, Agathocleous M, Murphy MM, Hu Z, Huddlestun SE,ZhaoZ,Leitch AM,Johnson TM,DeBerardinis RJ and Morrison SJ: Oxidative stress inhibits distant metastasis by human melanoma cells. Nature 527: 186-191, 2015.

67. Palmer LJ, Cooper PR, Ling MR, Wright HJ, Huissoon A and Chapple IL: Hypochlorous acid regulates neutrophil extracellular trap release in humans. Clin Exp Immunol 167: 261-268, 2012.

68. Prokopowicz ZM, Arce F, Biedroń R, Chiang CL, Ciszek M, Katz DR, Nowakowska M, Zapotoczny S, Marcinkiewicz J and Chain BM: Hypochlorous acid: A natural adjuvant that facilitates antigen processing, cross-priming, and the induction of adaptive immunity. J Immunol 184: 824-835, 2010.

69. Zhou R, Huang WJ, Ma C, Zhou Y, Yao YQ, Wang YX, Gou LT, Yi C and Yang JL: $\mathrm{HOCl}$ oxidation-modified CT26 cell vaccine inhibits colon tumor growth in a mouse model. Asian Pac J Cancer Prev 13: 4037-4043, 2012.

70. Chiang CL, Kandalaft LE, Tanyi J, Hagemann AR, Motz GT, Svoronos N, Montone K, Mantia-Smaldone GM, Smith L, Nisenbaum HL, et al: A dendritic cell vaccine pulsed with autologous hypochlorous acid-oxidized ovarian cancer lysate primes effective broad antitumor immunity: From bench to bedside. Clin Cancer Res 19: 4801-4815, 2013.

71. Tanyi JL, Bobisse S, Ophir E, Tuyaerts S, Roberti A, Genolet R, Baumgartner P, Stevenson BJ, Iseli C, Dangaj D, et al: Personalized cancer vaccine effectively mobilizes antitumor $\mathrm{T}$ cell immunity in ovarian cancer. Sci Transl Med 10: eaao5931, 2018.

This work is licensed under a Creative Commons

Attribution-NonCommercial-NoDerivatives 4.0 International (CC BY-NC-ND 4.0) License. 